\title{
KONDISI PENGELOLAAN, PENDIDIK, DAN SARANA PRASARANA SEKOLAH DASAR NEGERI DI PROVINSI BANTEN
}

\author{
Sugilar (gilar@ut.ac.id) \\ UPBJJ-UT Makassar
}

\begin{abstract}
The purpose of this study is to describe the condition of the management, educators and infrastructure of public primary schools in Banten province based on the parameters of national education standards. The samples of this study consisted of 78 in many schools under studied. The standards that were achieved in the areas of management such as selfevaluation and its utilization for school development planning do not apply optimally. Also teacher educational qualifications and in-job-training, and infrastructure or facilities. The study recommended that those specific matters would be the main concern in future educational improvement in Banten province.
\end{abstract}

Key words: Banten province, conditions, public primary schools

PP (Peraturan Pemerintah) Nomor 19 Tahun 2005 menyebutkan bahwa standar nasional pendidikan adalah kriteria minimal tentang sistem pendidikan di seluruh wilayah hukum Negara Kesatuan Republik Indonesia. Terdapat delapan (8) lingkup standar nasional pendidikan, yaitu: standar isi, standar proses, standar kompetensi lulusan, standar pendidik dan tenaga kependidikan, standar sarana dan prasarana, standar pengelolaan, standar pembiayaan, dan standar penilaian pendidikan. Tulisan ini memfokuskan pada sarana prasarana. Sarana dan prasarana sekolah merupakan salah satu komponen yang dianggap memiliki peranan besar terhadap peningkatan mutu pendidikan. Bank Dunia (1989) memperlihatkan bahwa guru, manajemen, dan sarana serta prasarana merupakan penentu mutu pendidikan masing-masing sebesar 34\%, 22\%, dan 26\% di negara-negara berkembang.

Tujuan PP (Peraturan Pemerintah) Nomor 19 Tahun 2005 tentang standar nasional pendidikan adalah meningkatkan mutu pendidikan yang tercermin dalam hasil belajar siswa. Mengingat PP tersebut relatif baru diterbitkan, informasi yang selama ini tersedia, misalnya dalam Indonesia Educational Statistics in Brief 2004/2005 (MONE, 2005), belum meliputi parameter dalam standar nasional pendidikan.

Provinsi Banten merupakan provinsi baru. Pada tanggal 4 Oktober 2004, DPR RI menyetujui RUU Pemebentukan Provinsi Banten. Pembangunan sektor pendidikan khususnya penuntasan wajib belajar 9 tahun di Provinsi Banten dinilai masih tertinggal. Hal ini diungkapkan oleh Menteri Pendidikan Nasional dalam sambutannya pada Puncak Peringatan Hari Pendidikan Nasional 2006 (Pikiran Rakyat, 4 Mei 2006). Selain itu, MONE (2005:127) menunjukkan bahwa angka melanjutkan sekolah (continuation rate) dari jenjang sekolah menengah atas ke jenjang pendidikan tinggi di Provinsi Banten hanya mencapai 8,14\%. Angka ini secara nasional tergolong rendah. 
Berdasarkan latar belakang masalah yang telah dikemukakan, rumusan masalah dalam penelitian ini adalah Bagaimana kondisi sarana prasarana SD di Provinsi Banten berdasarkan parameter standar nasional pendidikan?

\section{METODOLOGI}

Subyek penelitian adalah SDN Negeri yang berada di Provinsi Banten. Sampel dipilih dari 5 (lima) kluster kabupaten/kota akan dipilih secara acak 2 (dua) kabupaten/Kota. Dari masing-masing kabupaten/kota akan dipilih masing-masing 5 kecamatan sebagai kluster tingkat berikutnya. Salah satu dari 5 kecamatan tersebut dipilih secara purposif kecamatan kota kabupaten/kota. Sisanya, yaitu 4 kecamatan, dipilih secara acak dari kecamatan di luar kecamatan kota kabupaten/kota. Untuk setiap kecamatan sampel dipilih secara acak 10 SDN. Penelitian dilakukan pada tahun 2006.

\section{HASIL DAN PEMBAHASAN}

\section{Pengelolaan Sekolah}

Variabel pengelolaan sekolah terdiri dari 6 (enam) indikator, yaitu: (a) pelaksanaan evaluasi diri, (b) visi, misi dan tujuan, (c) perencanaan, (d) pelaksanaan, (e) pemeriksaan / evaluasi, dan (f) pelaporan. Sebanyak 41,0\% sekolah telah melakukan evaluasi diri. Dari sekolah yang melakukan evaluasi diri tersebut hanya sebanyak $16,7 \%$ saja yang menggunakanya untuk perencanaan pengembangan sekolah. Sebagai tindak lanjut dari hasil evaluasi diri tersebut sebuah sekolah menyatakan sebagai berikut:

Hasil evaluasi diri kami gunakan untuk penyempurnaan KBM dan administrasi sekolah serta perbaikan yang masih kurang, mempertahankan yang sudah baik dan melengkapi yang ada.

Sebaran sekolah yang memiliki visi, misi, dan tujuan sekolah dapat dilihat pada Tabel 1. Berdasarkan data pada Tabel 1, sebagian besar sekolah telah memiliki visi, misi, dan tujuan.

Tabel 1. Keberadaan Visi, Misi, dan Tujuan Sekolah

\begin{tabular}{lcc}
\hline Keberadaan Visi, Misi, dan Tujuan & $\mathrm{F}$ & $\%$ \\
\hline Visi & 65 & 83,3 \\
Misi & 66 & 84,6 \\
Tujuan & 45 & 57,7 \\
\hline
\end{tabular}

Keberadaan rencana kerja tahunan menunjukkan mutu pengelolaan di suatu sekolah. Tabel 2 menyajikan sebaran keberadaan rencana kerja tahunan di sekolah-sekolah.

Tabel 2. Keberadaan Rencana Kerja Tahunan

\begin{tabular}{lll}
\hline Keberadaan Rencana Kerja Tahunan & F & $\%$ \\
\hline Ada & 73 & 93,6 \\
Tidak ada & - & - \\
Tidak Mengisi & 5 & 6,4 \\
\hline
\end{tabular}

Sekolah-sekolah mencantumkan beberapa hal dalam rencana kerja tahunan tersebut seperti yang disajikan pada Tabel 3. 
Tabel 3. Rencana Kerja Tahunan

\begin{tabular}{lcc}
\hline \multicolumn{1}{c}{ Unsur Rencana Kerja Tahunan } & F & $\%$ \\
\hline $\begin{array}{l}\text { Kalender pendidikan (jadwal pembelajaran, ulangan, ujian, } \\
\text { kegiatan ekskul, libur) }\end{array}$ & 62 & 79,5 \\
$\begin{array}{l}\text { Penugasan pendidik pada kelas atau mata pelajaran } \\
\text { Buku teks yang digunakan pada masing-masing mata }\end{array}$ & 50 & 64,1 \\
$\begin{array}{l}\text { pelajaran } \\
\text { Jadwal penggunaan dan pemeliharaan sarana \& prasarana }\end{array}$ & 48 & 61,5 \\
$\begin{array}{l}\text { Pengadaan, penggunaan, dan persediaan minimal bahan habis } \\
\text { pakai }\end{array}$ & 40 & 51,3 \\
$\begin{array}{l}\text { Program peningkatan mutu pendidikan } \\
\text { Jadwal rapat Dewan Pendidik, rapat satuan pendidikan dengan }\end{array}$ & 50 & 61,5 \\
komite sekolah & 50 & 47,4 \\
$\begin{array}{l}\text { Rencana anggaran pendapatan dan belanja satuan pendidikan } \\
\text { Jadwal penyusunan laporan akuntabilitas dan kinerja satuan }\end{array}$ & 56 & 72 \\
$\begin{array}{l}\text { pendidikan untuk satu tahun terak1hir } \\
\text { Lainnya }\end{array}$ & 42 & 53,8 \\
\hline
\end{tabular}

Berdasarkan tabel di atas, rencana kerja tahun belum seluruhnya mencantumkan hal-hal yang telah diatur dalam stándar rencana sekolah. Misalnya, program peningkatan mutu sekolah hanya dimasukkan kedalam rencana kerja tahunan oleh 47,4\% sekolah sampel.

Pemantauan terhadap pelaksanaan program di sekolah dilaksanakan pada $73,1 \%$ sekolah. Terdapat 3,8\% sekolah yang menyatakan belum/tidak mendapat evaluasi/pemantauan terhadap pelaksanaan programnnya. Informasi mengenai pelaksanaan evaluasi/pemantauan di sekolah disajikan pada Tabel 4

Tabel 4. Frekuensi Pemantauan Pelaksanan Program

\begin{tabular}{llr}
\hline $\begin{array}{l}\text { Apakah pemantauan terhadap pelaksanaan program sudah } \\
\text { dilaksanakan? }\end{array}$ & $\mathrm{F}$ & $\%$ \\
\hline Ya & 57 & 73,1 \\
Tidak & 3 & 3,8 \\
Tidak Menjawab & 18 & 23,1 \\
\hline
\end{tabular}

Substansi pemantauan meliputi hal-hal seperti tercantum pada Tabel 5. Berdasarkan data pada Tabel 5, pelaksanaan pemantauan pada dasarnya mengacu pada hal-hal yang diharuskan dalam substansi evaluasi.

Tabel 5. Substansi Pemantauan Pelakasanaan Program

\begin{tabular}{lcc}
\hline Substansi Pemantauan & F & $\%$ \\
\hline Tingkat kehadiran peserta, kalender pendidididik, pendidik, dan & 44 & 66,4 \\
tenaga kependidikan & & \\
Pelaksanaan kurikulum satuan pendidikan & 46 & 59,0 \\
Hasil belajar peserta didik & 45 & 57,7 \\
Realisasi anggaran & 35 & 44,9 \\
\hline
\end{tabular}


Pelaporan terhadap pelaksanaan program sekolah dilakukan oleh berbagai unsur seperti terlihat pada Tabel 6. Dalam pelaksanaan pengelolaan sekolah, berbagai pihak perlu membuat pelaporan pelaksanaan di antaranya guru, tenaga kependidikan, kepala sekolah dan pengawas atau penilik.

Tabel 6. Pihak Pembuat Pelaporan Pelaksanaan Program Sekolah

\begin{tabular}{lcl}
\hline Pihak Pembuat Pelaporan pelaksanaan program sekolah & F & $\%$ \\
\hline Guru & 49 & 62,8 \\
Tenaga Kependidikan & 29 & 37,2 \\
Kepala Sekolah & 46 & 59 \\
Pengawas atau Penilik & 34 & 43,6 \\
\hline
\end{tabular}

\section{Kondisi Pendidik}

Variabel kondisi pendidik terdiri dari indikator-indikator (a) kecukupan guru yang dilihat dari rasio guru dengan jumlah kelas dan jumlah siswa, (b) jenjang pendidikan terakhir, (c) pengalaman mengajar, dan (d) pendidikan serta pelatihan dalam jabatan untuk pengembangan profesi. Statistik rasio jumlah guru terhadap jumlah rombongan belajar dan rasio jumlah guru terhadap jumlah siswa dapat dilihat pada Tabel 7.

Tabel 7. Statistik Rasio Guru terhadap Rombongan Belajar dan Siswa

\begin{tabular}{lcccc}
\hline & Rata-rata & Maksimum & Minimum & Simpangan Baku \\
\hline Rasio Guru terhadap Rombel & 0,88 & 2,44 & 0,14 & 0,37 \\
Rasio Guru terhadap Siswa & 30,67 & 70,58 & 11,22 & 11,23 \\
\hline
\end{tabular}

Pada Tabel 7 tampak bahwa secara rata-rata seorang guru umumnya menangani tidak lebih dari satu kelas. Meskipun demikan, di beberapa sekolah seorang guru dapat menangani lebih dari dua kelas. Walaupun secara rata-rata, rasio guru-siswa sudah mendekati standar yang ditetapkan oleh BNSP, yaitu sebesar 30, namun masih ada sekolah dengan rasio lebih dari 70 siswa per guru.

Sebaran jenjang pendidikan terakhir para guru yang menjadi sampel penelitian ini adalah seperti dicantumkan dalam Tabel 8.

Tabel 8. Sebaran Jenjang Pendidikan

\begin{tabular}{lrc}
\hline \multicolumn{1}{c}{ Jenjang Pendidikan } & $\mathrm{F}$ & $\%$ \\
\hline SLTA & 5 & 1,0 \\
SPG & 21 & 4,2 \\
D-I nonkependidikan & & \\
D-I kependidikan & 1 & 0,2 \\
D-II nonkependidikan & 1 & 0,2 \\
D-II kependidikan & 341 & 67,5 \\
D-III nonkependidikan & & \\
D-III kependidikan & 9 & 1,8 \\
D-IV nonkependidikan & & \\
D-IV kependidikan & & \\
S1 nonkependidikan & 6 & 1,2 \\
S1 kependidikan & 117 & 23,2 \\
S2/S3 nonkependidikan & 1 & 0,2 \\
S2/S3 kependidikan & 2 & 0,4 \\
\hline
\end{tabular}


Dari Tabel 8 tampak bahwa sebagian besar guru $(67,5 \%)$ berlatar belakang pendidikan D2 Kependidikan. Sedangkan guru dengan pendidikan S1 baru mencapai 23,2\%. Dengan demikian, masih diperkenankan upaya yang keras untuk mencapai jumlah guru SD yang berpendidikan S1. Pengalaman mengajar guru dinyatakan dalam Tabel 9. Pengalaman mengajar pada Tabel 9 belum seluruhnya memperhitungkan pengalaman mengajar di sekolah-sekolah sebelumnya.

Tabel 9. Pengalaman Mengajar Guru

\begin{tabular}{rrr}
\hline Pengalaman Mengajar & $F$ & $\%$ \\
\hline $1-5$ tahun & 198 & 39,44 \\
$6-10$ tahun & 116 & 23,10 \\
$11-15$ tahun & 91 & 18,12 \\
$>15$ tahun & 97 & 19,32 \\
\hline
\end{tabular}

Banyaknya pendidikan dan pelatihan dalam jabatan yang pernah diikuti oleh guru pada lima tahun terakhir ini dinyatakan dalam Tabel 10.

Tabel 10. Pendidikan dan Pelatihan Dalam jabatan

\begin{tabular}{|c|c|c|}
\hline $\begin{array}{l}\text { Banyaknya Pendidikan \& Pelatihan yang pernah } \\
\text { diikuti }\end{array}$ & $\mathrm{F}$ & $\%$ \\
\hline Tidak pernah & 385 & 68,14 \\
\hline $1-3$ kali & 141 & 24,95 \\
\hline $4-6$ kali & 39 & 6,90 \\
\hline $7-9$ kali & - & \\
\hline$>9$ & - & \\
\hline
\end{tabular}

Dari Tabel 10 terlihat bahwa guru kurang mendapat kesempatan mengikuti pendidikan dan pelatihan dalam jabatan. Sebanyak 68,14\% guru-guru tidak pernah mendapatkan pendidikan pelatihan dalam jabatan selama lima tahun terakhir.

\section{Sarana Prasarana}

Indikator yang dikaji untuk variabel sarana \& prasarana meliputi ketersediaan dan kecukupan serta kualitas ruang belajar, ruang kepala sekolah, ruang guru, tempat berolahraga, tempat ibadah, perpustakaan, laboratorium, tempat bermain, tempat berkreasi, sumber belajar lain (termasuk penggunaan teknologi dan komunikasi).

Kecukupan ruang kelas ditunjukkan oleh rasio jumlah kelas terhadap rombongan belajar. Rasio kurang dari 1 menunjukkan kekurangan kelas sehingga sekolah tersebut menggunakan dua waktu belajar, yaitu kelas pagi dan kelas siang. Hasil penelitian menunjukkan bahwa rata-rata rasio kelas dengan rombel sebesar 0,72. Ini berarti masih terdapat kekurangan ruang kelas. Bahkan ada satu sekolah dengan rasio kelas-rombelnya hanya 0,42 . Ini berarti kebutuhan ruang kelas pada sekolah tersebut baru tercukupi sebesar $42 \%$.

Keberadaan ruang kepala sekolah yang terpisah dengan ruang kelas maupun ruang guru menunjukkan ketersediaan sarana prasarana sekolah yang memadai. Pada Tabel 11 tampak bahwa tidak semua sekolah memiliki ruang kepala sekokah yang memadai. Hanya 29,5\% sekolah yang memiliki ruang kepala sekolah yang khusus diperuntukkan bagi kepala sekolah. 
Tabel 11. Ketersediaan Ruang Kepala Sekolah

\begin{tabular}{lrr}
\hline Keberadaan Ruang Kepala Sekolah & $F$ & $\%$ \\
\hline Ada dan terpisah & 23 & 29,5 \\
Ada tetapi menyatu dengan fungsi lain & 42 & 53,8 \\
Tidak ada & 6 & 7,7 \\
(Tidak menjawab) & 7 & 9,0 \\
\hline
\end{tabular}

Ketersediaan ruang guru di sekolah ditampilkan pada Tabel 12. Dari tabel tampak bahwa ruang guru tersedia di 57,7\% sekolah. Kebanyakan ruang guru tersebut menyatu dengan ruang kepala sekolah.

Tabel 12. Ketersediaan Ruang Guru

\begin{tabular}{lcc}
\hline Keberadaan Ruang Guru & $F$ & $\%$ \\
\hline Ada & 45 & 57,7 \\
Tidak & 21 & 26,9 \\
(Tidak menjawab) & 12 & 15,4 \\
\hline
\end{tabular}

Tempat berolahraga merupakan kelengkapan sarana dan prasarana sekolah. Tempat berolahraga dapat saja menyatu dengan fungsi-fungsi lain, tetapi tempat berolahraga yang terpisah dan khusus untuk berolahraga saja menunjukkan bahwa sekolah tersebut memiliki sarana olahraga yang baik. Terdapat $14,1 \%$ sekolah yang memiliki tempat khusus untuk berolahraga.

Tabel 13. Tempat Berolahraga

\begin{tabular}{lcc}
\hline \multicolumn{1}{c}{ Keberadaan Tempat Berolahraga } & $\mathrm{F}$ & $\%$ \\
\hline Ada dan terpisah & 11 & 14,1 \\
Ada tetapi menyatu dengan fungsi lain & 27 & 34,6 \\
Tidak ada & 27 & 34,6 \\
(Tidak menjawab) & 13 & 16,7 \\
\hline
\end{tabular}

Hasil pendidikan diharapkan bukan hanya meliputi aspek kognisi saja, melainkan juga meliputi pembinaan keagamaan. Tempat beribadah merupakan sarana untuk mengembangkan perilaku keagamaan siswa. Tabel 14 memperlihatkan keberadaan sarana beribadah di sekolah.

Tabel 14. Tempat Beribadah

\begin{tabular}{lcc}
\hline Keberadaan Tempat Beribadah & $\mathrm{F}$ & $\%$ \\
\hline Ada dan terpisah & 10 & 12,8 \\
Ada tetapi menyatu dengan fungsi lain & 13 & 16,7 \\
Tidak ada & 48 & 61,5 \\
(Tidak menjawab) & 7 & 9 \\
\hline
\end{tabular}

Untuk mengembangkan pembelajaran yang berpusat pada siswa. Belajar aktif siswa merupakan salah satu kondisi yang diinginkan dalam pembelajaran yang berpusat pada siswa. Peran guru adalah sebagai fasilitator belajar, oleh karena itu, perpustakaan merupakan sarana yang sangat diperlukan supaya siswa dapat menggali informasi dan pemahaman secara mandiri. Tabel 15 menggambarkan keberadaan perpustakaan di sekolah-sekolah. 
Tabel 15. Keberadaan Perpustakaan Sekolah

\begin{tabular}{lrr}
\hline Keberadaan Perpustakaan Sekolah & F & $\%$ \\
\hline Ada & 31 & 39,7 \\
Tidak & 41 & 52,6 \\
(Tidak menjawab) & 6 & 7,7 \\
\hline
\end{tabular}

Dari Tabel 15 tampak bahwa hanya 39,7\% sekolah yang memiliki perpustakaan. Dari sekolah yang memiliki perpustakaan tersebut, jumlah koleksi buku yang tersedia belum mencukupi seperti yang tampak pada Tabel 16.

Tabel 16. Koleksi Buku Perpustakaan Sekolah

\begin{tabular}{llllc}
\hline \multicolumn{1}{c}{ Jenis Buku } & $\begin{array}{l}\text { Jumlah } \\
\text { Sekolah yang } \\
\text { memiliki } \\
\text { Koleksi (N) }\end{array}$ & $\begin{array}{l}\text { Rata-rata } \\
\text { Jumlah Koleki }\end{array}$ & $\begin{array}{l}\text { Jumlah } \\
\text { Koleksi } \\
\text { Tertinggi }\end{array}$ & $\begin{array}{l}\text { Jumlah } \\
\text { Koleksi } \\
\text { Terendah }\end{array}$ \\
\hline Buku Teks & 21 & 294 & 900 & 20 \\
Buku Pengayaan & 16 & 95 & 350 & 6 \\
Buku Rujukan & 12 & 11 & 40 & 2 \\
Buku Fiksi & 12 & 110 & 520 & 2 \\
\hline
\end{tabular}

Dari 12 sekolah sampel yang memiliki perpustakaan, hanya satu sekolah yang memiliki ruang khusus untuk perpustakaan tersebut, seperti yang tampak pada Tabel 17. Ini berarti pada sebagian besar sekolah yang memiliki perpustakaan tidak memiliki ruang khusus tetapi menyatu dengan fungsi lain.

Tabel 17. Keberadaan Ruang Perpustakaan Sekolah

\begin{tabular}{lrc}
\hline Keberadaan Perpustakaan Sekolah & $\mathrm{F}$ & $\%$ \\
\hline Ada & 1 & 8,3 \\
Tidak & 11 & 91,7 \\
(Tidak menjawab) & - & - \\
\hline
\end{tabular}

Terdapat 28 sekolah yang memiliki tempat bermain khusus, sedangkan 37 sekolah memiliki tempat bermain yang menyatu dengan fungsi lain, seperti yang terlihat pada Tabel 18 di bawah ini.

Tabel 18. Tempat Bermain di Sekolah

\begin{tabular}{lcc}
\hline Keberadaan Tempat Bermain & $F$ & $\%$ \\
\hline Ada & 28 & 35,9 \\
Tidak (tempat bermain menyatu dengan tempat & 37 & 47,4 \\
untuk fungsi lain) & & \\
(Tidak menjawab) & 13 & 16,7 \\
\hline
\end{tabular}

Hasil penelitian menunjukkan bahwa terdapat 5,1\% sekolah yang belum memiliki aliran listrik. Bagi sekolah yang tersedia lairan listrik, besarnya daya listrik yang dimiliki oleh sekolah tersebut berkisar antara 450 watt - 900 watt, tetapi ada beberapa sekolah memiliki daya listrik antara 1400 watt sampai 1800 watt. Dari 78 sekolah sampel yang diteliti, terdapat 25 sekolah yang memiliki telepon. Tetapi ada yang tidak memiliki telepon lebih banyak lagi, yaitu 47 sekolah. Terdapat 25 
sekolah yang memiliki komputer, sedangkan 47 sekolah tidak memiliki komputer. Secara umum pengadaan komputer rata-rata setiap sekolahnya adalah sebanyak 1 set komputer. Tapi ada juga satu sekolah yang memiliki 5 set komputer. Sedangkan untuk pengaksesan ke internet, terdapat 71 sekolah yang tidak dapat mengakses ke internet.

Hal lain yang menjadi fokus pengamatan di sekolah adalah sarana pendidikan yang dimiliki sekolah yang berkaitan dengan kelancaran pelaksanaan proses belajar mengajar di kelas, yaitu ketersediaan aliran listrik PLN, telepon, komputer dan akses internet.

\section{KESIMPULAN DAN SARAN}

Dari enam indikator pengelolaan sekolah, yaitu: (a) pelaksanaan evaluasi diri, (b) visi, misi dan tujuan, (c) perencanaan, (d) pelaksanaan, (e) pemeriksaan / evaluasi, dan (f) pelaporan, pelaksanaan evaluasi diri merupakan komponen pengelolaan yang belum banyak dilakukan oleh sekolah. Terdapat 41,0\% sekolah yang sudah melakukan evaluasi diri. Dari sekolah yang melakukan evaluasi diri tersebut hanya $16,7 \%$ yang digunakan/dimanfaatkan untuk perencanaan pengembangan sekolah. Untuk itu, sekolah perlu didorong melakukan evaluasi diri untuk digunakan dalam perencanaan pengembangan sekolah, dan Provinsi Banten seyogyanya memfasilitasi sekolah untuk melakukan evaluasi diri.

Kondisi pendidik di Provinsi Banten masih sangat memerlukan peningkatan dalam kualifikasi guru, mengingat sebagian besar guru $(67,5 \%)$ masih berpendidikan D2 Kependidikan, sedangkan guru dengan pendidikan S1 mencapai 23,2\%. Dengan demikian, untuk meningkatkan jumlah guru SD yang berpendidikan S1 perlu upaya yang terencana. Pendidikan guru SD secara jarak jauh yang ditawarkan UT merupakan alternatif pemecahan masalah peningkatan kualifikasi guru. Selain itu, pelatihan dalam jabatan untuk guru-guru juga perlu ditingkatkan. Hasil penelitian menunjukkan bahwa sebanyak 68,14\% guru-guru tidak pernah mendapatkan pendidikan pelatihan dalam jabatan selama lima tahun terakhir.

Kondisi sarana dan prasarana pendidikan yang perlu untuk diperbaiki ialah perpustakaan sekolah. Pengembangan pembelajaran yang berpusat pada siswa mengutamakan belajar aktif oleh siswa. Peran guru merupakan fasilitator belajar dan perpustakaan merupakan sarana yang sangat diperlukan supaya siswa dapat menggali informasi dan pemahaman secara mandiri. Hanya 39,7\% sekolah yang memiliki perpustakaan. Dari sekolah yang memiliki perpustakaan tersebut, jumlah koleksi buku yang tersedia belum sesuai dengan standar sarana perpustakaan. Selain itu, dari 12 sekolah sampel yang memiliki perpustakaan, hanya satu sekolah yang memiliki ruang khusus untuk perpustakaan tersebut.

\section{REFERENSI}

Depdiknas (2001). Manajemen peningkatan mutu berbasis sekolah. Buku 1 dan 2. Jakarta; Depdiknas.

Direktorat Dikmenum. (2000). Manajemen peningkatan mutu berbasis sekolah. Jakarta: Depdiknas. Minstry of National Education (MONE). (2005). Indonesia educational statistics in brief 2004/2005. Jakarta: Minstry of National Education

World Bank. (1989). Basic education study. Washington, D.C.: World Bank 